\title{
Clinical management guidelines for pandemic (H1N1) 2009 virus infection in the Eastern Mediterranean Region: technical basis and overview
}

\author{
S. Al Hajjar, M. M. Malik, ${ }^{2}$ Z. Hallaj, ${ }^{2}$ H. El-Bushra, ${ }^{2}$ M. Opoka ${ }^{2}$ and A.R. Mafi ${ }^{2}$
}

$$
\begin{aligned}
& \text { في إقليم شرق المتوسط: الأساس التقني والنظرة العامة } 2009 \text { (H1N1) الدلائل الإرشادية للتدبير السريري لجائحة فيروس }
\end{aligned}
$$

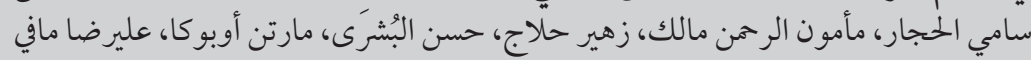

$$
\begin{aligned}
& \text { الخلاصـة: خلال ربيع 2009، أدى فيروس A1N1 الجمديد ومصدره من الخنزير إلى عدوى البشر وإصابتهم باعتلال تنفسي حاد في المكسيك. }
\end{aligned}
$$

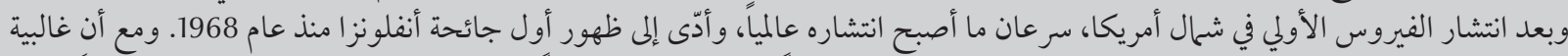

ABSTRACT During the spring of 2009, a novel influenza A (H1N1) virus of swine origin caused human infection and acute respiratory illness in Mexico. After initially spreading in North America, the virus spread globally resulting in the first influenza pandemic since 1968. While the majority of illnesses caused by pandemic (H1N1) 2009 were mild and self-limiting, severe complications, including fatalities, were also reported. In view of the increasing number of laboratory-confirmed cases and deaths from pandemic (H1N1) 2009 in the Eastern Mediterranean Region of the World Health Organization, the Regional Office convened a consultation meeting of experts involved in the clinical management of patients infected with pandemic (H1N1) 2009 virus. The consultation resulted in developing an interim guidance and algorithm for clinical management of pandemic (H1N1) 2009 virus infection in health-care settings. This paper describes the process, the technical basis and the components of this interim guidance.

Lignes directrices pour la prise en charge clinique de l'infection par le virus de la grippe pandémique (H1N1) 2009 dans la Région de la Méditerranée orientale : données techniques initiales et présentation générale

RÉSUMÉ Au cours du printemps de l'année 2009 au Mexique, un nouveau virus grippal A (H1N1) d'origine porcine a été la cause d'infections et de pathologies respiratoires aiguës chez l'homme. Après s'être d'abord propagé en Amérique du Nord, le virus s'est étendu mondialement pour devenir la première pandémie grippale depuis 1968. Alors que la majorité des pathologies causées par la grippe pandémique (H1N1) 2009 était modérée et à guérison spontanée, des complications graves, y compris des décès, ont également été signalés. Compte tenu du nombre croissant d'infections et de décès par le virus de la grippe pandémique (H1N1) 2009 confirmés en laboratoire dans la Région OMS de la Méditerranée orientale, le Bureau régional a convoqué une réunion consultative d'experts impliqués dans la prise en charge clinique de patients infectés par ce virus. La consultation a permis d'élaborer des lignes directrices temporaires et un algorithme pour la prise en charge clinique de l'infection par le virus de la grippe pandémique (H1N1) 2009 en milieu de soins. Le présent article décrit le processus, les données techniques et les composantes de ces lignes directrices temporaires. 


\section{Background}

At the beginning of April 2009, human infections with a novel strain of influenza A $(\mathrm{H} 1 \mathrm{~N} 1)$ virus emerged in Mexico [1]. After initially spreading among persons in the United States, Mexico and Canada, the virus spread globally, resulting in the first influenza pandemic since 1968 [2,3].

As of 6 August 2010, worldwide more than 214 countries and overseas territories or communities have reported laboratory-confirmed cases of pandemic (H1N1) 2009 virus infection, and there have been around 18500 deaths [4].

Kuwait and the United Arab Emirates were the first 2 countries in the World Health Organization Eastern Mediterranean Region (WHO-EMR) reporting confirmed cases of pandemic (H1N1) 2009 on 25 May 2009. Up to 6 August 2010, all 22 countries had reported laboratory-confirmed cases of infection, and 1019 deaths had been recorded [5].

\section{Epidemiology}

\section{Infection and illness}

Globally, most illnesses caused by the pandemic (H1N1) 2009 virus were acute and self-limiting, with the highest attack rates reported among children and young adults [6]. The median age of most of the reported cases was 12-25 years, and over $80 \%$ of cases occurred among the age group of 5-49 years [7]. The overall case fatality rate amongst the laboratory-confirmed cases was less than $0.5 \%[8]$.

\section{Transmission}

The mechanism of person-to-person transmission of pandemic (H1N1) 2009 virus appeared to be similar to those of seasonal influenza [6]. The main route of transmission was reported to be respiratory through inhalation of large-particle respiratory droplets, and possibly via droplet nuclei [9]. Explosive outbreaks and amplifications of cases have been noted in schools and closed community settings [10].

\section{Clinical features}

\section{Incubation period}

The incubation period was approximately $1.5-3$ days, which is similar to that of seasonal influenza [6,9]. Children and immunocompromised or immunosuppressed persons were contagious for longer periods.

\section{Clinical presentation}

The clinical manifestations of pandemic (H1N1) 2009 virus infection varied, ranging from afebrile upper respiratory illness to fulminant viral pneumonia. Most patients presenting for care showed typical influenza-like illness with fever and cough, sometimes accompanied by sore throat and rhinnorrhoea $[11,12]$.

\section{Risk groups and risk factors for severe disease}

Underlying medical conditions which are associated with complications from seasonal influenza were also risk factors for complications from pandemic (H1N1) 2009 virus infection. Globally, nearly three quarters of cases requiring hospitalization involved one or more underlying medical conditions including asthma, diabetes, heart or lung disease, neurologic disease, pregnancy, morbid obesity, autoimmune disorders and associated immunosuppressive therapies $[13,14]$.

\section{Clinical management}

The majority of individuals infected with pandemic (H1N1) 2009 virus were treated with simple supportive care at home using antipyretics (e.g. acetaminophen or ibuprofen).

The pandemic (H1N1) 2009 virus infection was susceptible to the neuraminidase inhibitors oseltamivir and zanamivir, but was almost always resistant to amantadine and rimantadine [15-17]. Early empirical treatment with neuraminidase inhibitors in patients with pandemic (H1N1) 2009 infection has been shown to have reduced the duration of hospitalization [18] and the risk of progression to severe disease requiring ICU admission or resulting in death [14].

Empiric antiviral therapy needs to be started for persons with suspected, probable or confirmed cases of pandemic (H1N1) 2009 infection for:

- Illness requiring hospitalization

- Progressive, severe or complicated illness regardless of previous health status and/or

- High risk groups for severe disease, which include:

- Children younger than 2 years

- Pregnant women up to 2 weeks post partum (regardless of how the pregnancy ended)

- Adults 65 years of age or older

- Persons younger than 19 years who are having long-term aspirin therapy

- Persons with medical conditions including asthma, neurological and neurodevelopmental conditions (including disorders of the brain, spinal cord, peripheral nerves and muscles, such as cerebral palsy) chronic obstructive lung disease, cardiac disease, diabetes mellitus, immunosuppressive conditions (including HIV/AIDS, and cancer).

Clinicians should consider empiric treatment with antibacterial drugs if bacterial co-infections are suspected during or after influenza. The use of high dose corticosteroids for pandemic (H1N1) 2009 infection is controversial; low-dose steroids may, however, be 
considered in patients with septic shock who require vasopressors [19-21].

\section{Development of guidelines: expert consultation}

In order to support the countries of the WHO EMR to manage human cases infected with pandemic (H1N1) 2009 virus in a standardized way, the Regional Office convened an international expert consultation meeting from 9 to 10 September 2009. The purpose of this meeting was to develop a clinical management guideline in order to optimize clinical care for human infections with pandemic (H1N1) 2009 virus across all countries in the Region.

Medical experts in the field of pulmonology, infectious diseases, public health, epidemiology, internal medicine, intensive care, microbiology and virology came together and reviewed the available international guidelines
$[22,23]$, published evidence and unpublished data on epidemiology and clinical manifestations of the disease. Following this expert consultation, an interim guidance and algorithms were developed on clinical management of pandemic ( $\mathrm{H} 1 \mathrm{~N} 1)$ virus infection [24]. The algorithms were intended to be used as a decision tree by clinicians to exercise their clinical judgment for treatment and care of patients with pandemic $\mathrm{H} 1 \mathrm{~N} 1$ virus infection.

The interim guidance on clinical management of pandemic (H1N1) 2009 virus infection used 4 case definitions of influenza (Table 1) for the purpose of clinical diagnosis and initial treatment decisions. These include (i) influenza-like illness (ILI), (ii) severe acute respiratory infection (SARI), (iii) acute respiratory infection (ARI) and (iv) influenza caused by pandemic (H1N1) 2009 virus infection.

Three categories of clinical manifestations have been seen during the current pandemic $[13,14]$ and these have been presented in the WHO Regional Office Interim Guidance:

- Mild illness characterized by fever (some patients had no fever), cough, sore throat, diarrhoea, myalgias, headache. Other frequent findings have included chills and malaise. Vomiting and diarrhoea have been reported in some patients, but no shortness of breath, dyspnoea, or severe dehydration.

- Progressive illness characterized by mild illness with clinical signs or symptoms suggesting a progression to severe illness, which include the following signs and symptoms (Table 2 shows differentiation between clinical signs in adults and in children under 5 years):

- chest pain, tachypnoea, or laboured breathing in children

- hypotension

- confusion or altered mental status

- severe dehydration or exacerbations of a chronic conditions (e.g. asthma, cardiovascular conditions)

\begin{tabular}{ll}
\hline Table 1 Case definition of influenza caused by pandemic (H1N1) 2009 virus infection \\
\hline Influenza-like illness (ILI) & $\begin{array}{l}\text { A person with sudden onset of fever }>38{ }^{\circ} \mathrm{C} \text { and } \geq 1 \text { of the following } 2 \text { respiratory } \\
\text { symptoms in the absence of other known causes: dry cough, sore throat }\end{array}$ \\
$\begin{array}{ll}\text { Severe acute respiratory illness } \\
\text { (SARI) }\end{array}$ & $\begin{array}{l}\text { A person meeting the case definition of influenza-like illness (above) AND shortness of } \\
\text { breath OR difficulty in breathing requiring hospital admission. }\end{array}$ \\
Acute respiratory infection (ARI) & $\begin{array}{l}\text { Acute respiratory tract illness that is caused by an infectious agent transmitted from person } \\
\text { to person. The onset of symptoms is typically rapid, over a period of hours to several } \\
\text { days. Symptoms include fever, cough, and often sore throat, coryza, shortness of breath, } \\
\text { wheezing, or difficulty breathing. }\end{array}$ \\
$\begin{array}{ll}\text { Confirmed case of Pandemic } \\
\text { (H1N1) 2009 }\end{array}$ & $\begin{array}{l}\text { An individual with an influenza-like illness with laboratory confirmed pandemic (H1N1) } \\
\text { real time reverse-transcription polymerase (RT-PCR) } \\
\text { viral culture. }\end{array}$ \\
$\begin{array}{l}\text { Probable case of Pandemic (H1N1) } \\
\text { Andividual with an influenza-like illness who is positive for influenza A that is } \\
\text { unsubtypable by real-time PCR, OR }\end{array}$ & $\begin{array}{l}\text { An individual with a clinically compatible illness or who died of an unexplained acute } \\
\text { respiratory illness who is considered to be epidemiologically linked to a probable or } \\
\text { confirmed case. } \\
\text { An individual with acute respiratory illness and fever (reported or documented fever), and } \\
\text { one of the followings; cough, sore throat, shortness of breath, difficulty in breathing or } \\
\text { chest pains with onset: } \\
\text { within } 7 \text { days of close contact with a person who is a probable or confirmed case of } \\
\text { pandemic (H1N1) 2009 virus infection, OR } \\
\text { within } 7 \text { days of travel to a country/community where there has been one or more } \\
\text { confirmed cases of pandemic (H1N1) 2009 virus infection, OR } \\
\text { Resides in a community where there is one or more confirmed cases of pandemic (H1N1) } \\
\text { 2009 virus infection. }\end{array}$ \\
\hline
\end{tabular}




\begin{tabular}{ll}
\hline Table 2 Clinical signs indicating rapid progression and need for urgent medical care \\
\hline In adults & In children \\
Difficulty in breathing or shortness of breath & Tachypnoea or laboured breathing \\
Pain or pressure in the chest or abdomen & Skin colour change, grey or blue \\
Episodes of sudden dizziness & Inadequate intake of oral fluids \\
Severe or continuous vomiting & Severe or continuous vomiting \\
Influenza-like illness that improves but then returns with fever & Influenza-like illness that improves but then returns with fever \\
and cough & and cough \\
Confusion & Irritable or not waking up \\
\hline
\end{tabular}

- Severe illness characterized by the following:

- profound hypoxemia, abnormal chest radiograph, and mechanical ventilation

- encephalitis or encephalopathy

- shock, multisystem organ failure

- myocarditis and rhabdomyolysis

- invasive secondary bacterial infection (e.g. pneumococcal disease).

When influenza viruses are known to be circulating in the community, patients presenting with mild influenza can be diagnosed on clinical and epidemiological grounds alone. Based on the clinical evidence and judgment, the Interim Guidance recommends empirical antiviral therapy with a neuraminidase inhibitor in appropriate dose (Table 3 ) as soon as possible (i) whenever the illness requires hospitalization; (ii) whenever the person shows signs of progressive illness; (iii) and/or whenever the person belongs to the high risk group for severe disease.

The clinical algorithms (Figures 1 and 2) for management of patients with pandemic (H1N1) 2009 virus infection, as presented in the Interim Guidance, can be applied to every patient diagnosed on the basis of clinical suspicion alone without waiting for laboratory confirmation. The Interim Guidance, however, emphasizes that all patients treated at home need to be instructed to return for follow-up should they develop any signs or symptoms of progressive disease or fail to improve within 72 hours of the onset of symptoms.

\section{Future directions}

As of 10 August 2010, the world has moved into the post-pandemic period [25]. Based on the knowledge about past influenza pandemics, pandemic (H1N1) 2009 virus is expected to continue to circulate as a seasonal virus for some years to come [25]. While the level of concern might have greatly diminished, vigilance on the part of national health authorities as well as treatment of all suspected influenza cases with standard care remain critical in the immediate post-pandemic

\begin{tabular}{|c|c|c|}
\hline Age group & Treatment (5 days) & Chemoprophylaxis (10 days) \\
\hline \multicolumn{3}{|c|}{ Oseltamivir } \\
\hline Adults & 75 mg twice per day & 75 mg once per day \\
\hline \multicolumn{3}{|l|}{ Children ( $\geq 12$ months) } \\
\hline$\leq 15 \mathrm{~kg}$ & 30 mg twice per day & 30 mg once per day \\
\hline $15-23 \mathrm{~kg}$ & 45 mg twice per day & 45 mg once per day \\
\hline $20-40 \mathrm{~kg}$ & 60 mg twice per day & 60 mg once per day \\
\hline$>40 \mathrm{~kg}$ & 75 mg twice per day & 75 mg once per day \\
\hline \multicolumn{3}{|l|}{ Children } \\
\hline $3-<12$ months & $3 \mathrm{mg} / \mathrm{kg} /$ dose twice per day & $3 \mathrm{mg} / \mathrm{kg} /$ dose once per day \\
\hline \multirow[t]{2}{*}{$0-<3$ months } & $3 \mathrm{mg} / \mathrm{kg} /$ dose twice per day & $\begin{array}{l}\text { Not recommended, unless situation } \\
\text { judged critical (limited data) }\end{array}$ \\
\hline & \multicolumn{2}{|c|}{ Zanamivir } \\
\hline Adults & $\begin{array}{l}2 \times 5 \mathrm{mg} \text { inhalations } \\
(10 \mathrm{mg} \text { total }) \text { twice per day }\end{array}$ & $\begin{array}{l}2 \times 5 \mathrm{mg} \text { inhalations } \\
(10 \mathrm{mg} \text { total }) \text { once per day }\end{array}$ \\
\hline $\begin{array}{l}\text { Children } \geq 7 \text { years for treatment; } \\
\text { children } \geq 5 \text { years for } \\
\text { chemoprophylaxis }\end{array}$ & $\begin{array}{l}2 \times 5 \mathrm{mg} \text { inhalations } \\
(10 \mathrm{mg} \text { total }) \text { twice per day }\end{array}$ & $\begin{array}{l}2 \times 5 \mathrm{mg} \text { inhalations } \\
(10 \mathrm{mg} \text { total }) \text { once per day }\end{array}$ \\
\hline
\end{tabular}




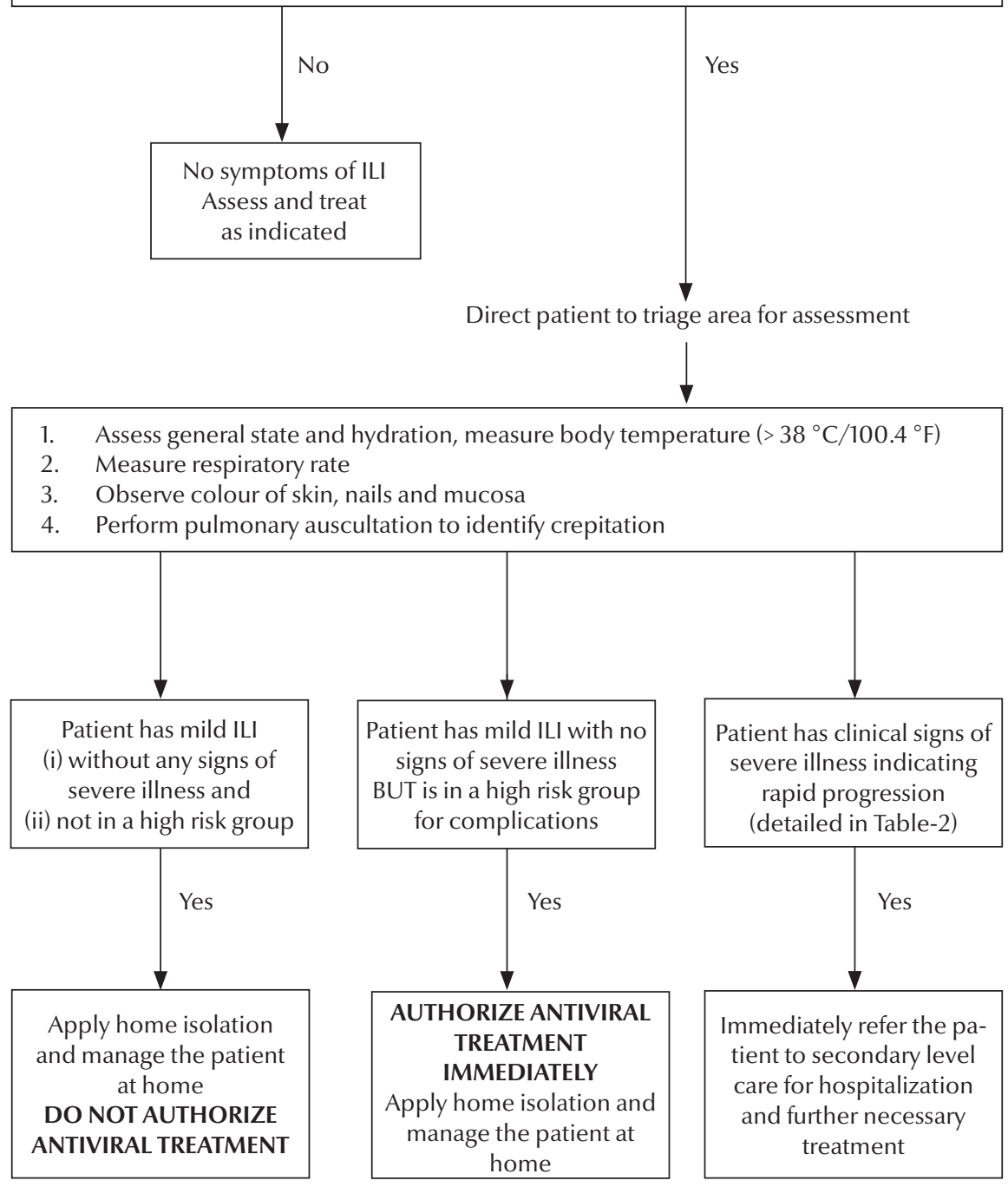

Direct patient to triage area for assessment

Infection control measures

Standard and droplet precautions

Patient: Surgical mask

Staff: Hand hygiene, mask, gown and gloves
Community protection

Patient: wears surgical mask, covers mouth and nostrils when coughing or sneezing and frequently washes hands

\section{The patient:}

- Avoids public transport

- Uses a surgical mask

- Covers mouth and nostrils during coughing and sneezing

- Avoids close contact

Figure 1 Algorithm for clinical management of patients at the primary health care level

period since the behaviour of pandemic (H1N1) 2009 virus can not be reliably predicted.

The Interim Guidance and the algorithms for clinical management of human infection with pandemic (H1N1) 2009 virus were developed in September 2009 based on clinical evidence and best clinical outcome following available treatment practices known globally at that time. The Interim
Guidance and its clinical algorithms were adopted by many countries in the Region. It is expected that this Interim Guidance will pave the way towards developing national clinical management protocols for influenza as well as other epidemic- and pandemic-prone acute respiratory infections in the countries of the Region. The uncertain evolution of the pandemic virus, however, highlights the importance that the treatment guidelines and the supplementary algorithms need to be revised and continuously updated as soon as new evidence on clinical manifestation of influenza in the post-pandemic period, antiviral resistance pattern, effectiveness of the currently available antivirals, and virulence of the circulating seasonal influenza virus become available in the post-pandemic period. 


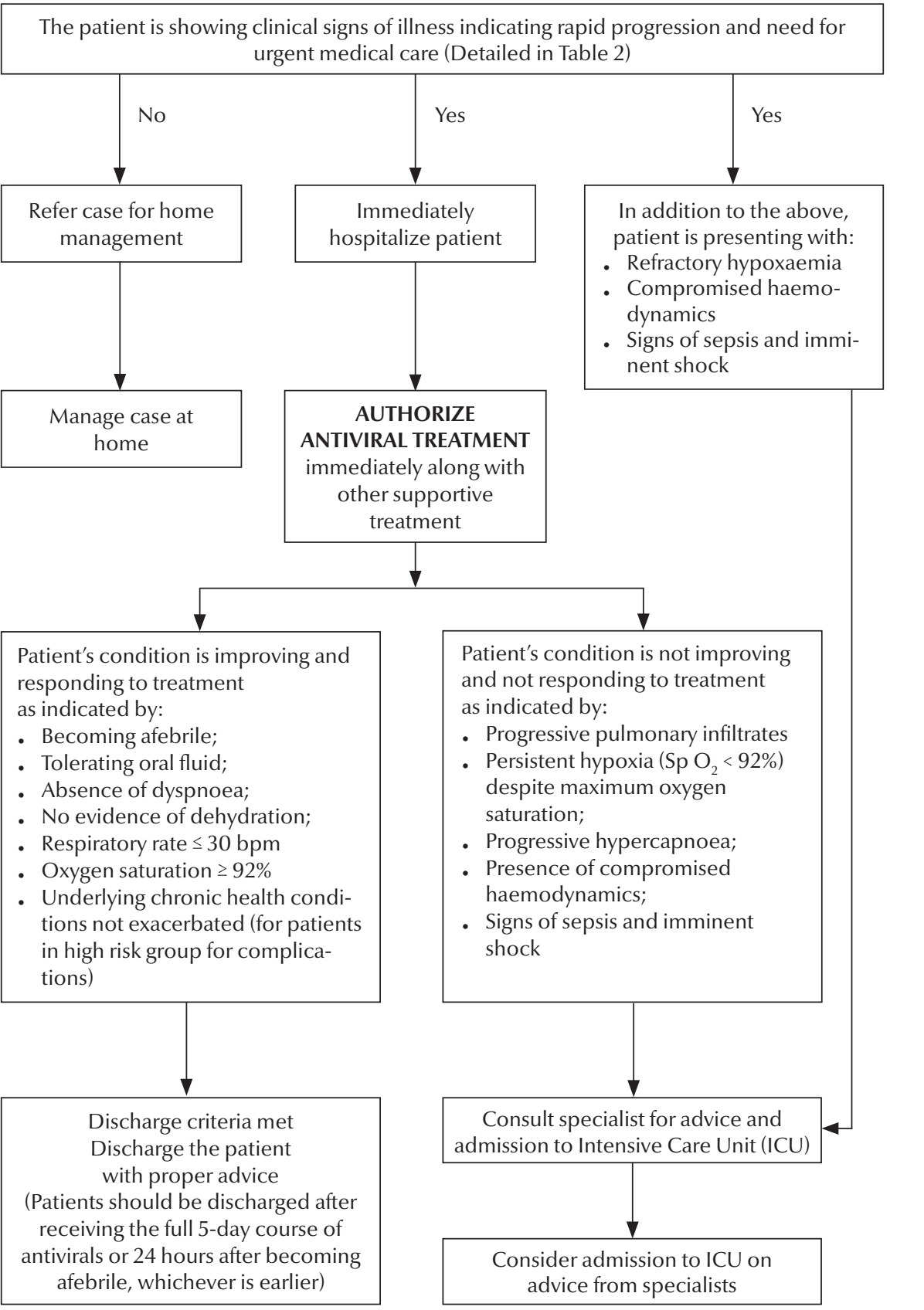

Standard and droplet precautions

Patient: Surgical mask Staff: Hand hygiene, mask, gown and gloves

Standard and droplet precautions

Patient: Surgical mask and strict isolation or cohorting. Isolation precaution may be discontinued after the patients has received antiviral treatment for 72 hours and remained afebrile for 24 hours even in the absence of antipyretics. Staff: Hand hygiene, mask, gown, gloves and eye protection if there is a risk of splash.

Figure 2 Algorithm for clinical management of patients at secondary or tertiary health care level

One of the best ways to evaluate this Interim Guidance would be to assess the diagnostic validity of its clinical algorithms prospectively in some selected clinical settings that should include both resource-intensive and resource-limited countries.
The effectiveness of clinical algorithms in truly detecting patients with suspected influenza needs to be assessed. Solid data on such an evaluation will increase the sensitivity and specificity of the clinical algorithms of the guidelines in detecting and identifying patients with suspected influenza, guide treatment decisions in the post-pandemic period, and ensure that no cases with potentially fatal outcome are missed by clinicians when using these algorithms as a decision tree to exercise their clinical judgement. 


\section{References}

1. López-Cervantes $\mathrm{M}$ et al. On the spread of the novel influenza A (H1N1) virus in Mexico. Journal of Infection in Developing Countries, 2009, 3:327-330.

2. Influenza-like illness in the United States and Mexico, 2009. Geneva, World Health Organization, 2009 (http://www.who. int/csr/don/2009_04_24/es/index.html, accessed 26 May 2009).

3. Pandemic (H1N1) 2009-update 60. Geneva, World Health Organization, 2009 (http://www.who.int/csr/ don/2009_10_02/en/index.html, accessed 5 October 2009).

4. Pandemic (H1N1) 2009-update 112. Geneva, World Health Organization, 2009 ( http://www.who.int/csr/ don/2009_1204/3n/index.html, accessed 10 August 2010).

5. Pandemic (H1N1) 2009 update. Cairo, World Health Organization. Eastern Mediterranean Regional Office, 2009. (http:// www.emro.who.int/csr/h1nl/index.html, accessed 10 June 2010).

6. Writing Committee of the $\mathrm{WHO}$ consultation on clinical aspects of pandemic (h1n1) 2009 influenza. Clinical aspects of pandemic 2009 influenza A (H1N1) virus infection. New England Journal of Medicine, 2010, 362:1708-1719.

7. Pandemic influenza A (H1N1) 2009 virus. Weekly Epidemiological Record, 2009, 85(49):505-516.

8. Wilson N, Baker MG. The emerging influenza pandemic: estimating the case fatality ratio. Euro Surveillance, 2009, 14(26):pii 19255.

9. Yang $\mathrm{Y}$ et al. The transmissibility and control of pandemic influenza A (H1N1). Science, 2009, 326:729-733.

10. Lessler J et al. Outbreak of 2009 pandemic influenza A (H1N1) at a New York City school. New England Journal of Medicine, 2009, 361:2628-2636.

11. Cao B et al. Clinical features of the initial cases of 2009 pandemic influenza A ( $\mathrm{H} 1 \mathrm{~N} 1$ ) virus infection in China. New England Journal of Medicine, 2009, 361:2507-2517.

12. Hackett $\mathrm{S}$ et al. Clinical characteristics of paediatric $\mathrm{H} 1 \mathrm{~N} 1 \mathrm{ad}-$ missions in Birmingham, UK. Lancet, 2009, 374:605-606.

13. Human infection with new influenza A (H1N1) virus, clinical observation from Mexico and other affected countries. Weekly Epidemiological Record, 2009, 84(21):185-196.

14. Jain S et al. Hospitalized patients with 2009 H1N1 influenza in the United States, April-June 2009. New England Journal of Medicine, 2009, 361:1935-1944.
15. Itoh $\mathrm{Y}$ et al. In vitro and in vivo characterization of new swine origin H1N1 influenza viruses. Nature, 2009, 460:1021-1025.

16. Oseltamivir-resistant pandemic (H1N1) 2009 influenza virus Stockholm, European Centre for Disease Prevention and Control, 2009 (http://www.ecdc.europa.eu/en/activities/ sciadvice/tests, accessed 10 December 2009).

17. Antiviral treatment options including intravenous peramivir for treatment of influenza in hospitalized patients for 2009-2010 season. Atlanta, United States Centers for Disease Control and Prevention, 2009 (http://www.cdc.gov/ h1n1flu/EUA/ Peramovir-recommendations.html, accessed 2 December 2009).

18. Patients hospitalized with 2009 pandemic influenza A (H1N1) - New York City, May 2009. MMWR Morbidity and Mortality Weekly Report, 2010, 58:1436-1440.

19. Intensive care patients with severe novel influenza A (H1N1) virus infections. Michigan, June 2009. MMWR Morbidity and Mortality Weekly Report, 2009, 58:(27):749-752.

20. Gomez-Gomez A et al. Severe pneumonia associated with pandemic (H1N1) 2009 outbreak, San Luis Potosí, Mexico. Emerging Infectious Diseases, 2010, 16(1):27-34.

21. Al Hajjar S, Mclntosh. The first influenza pandemic of the 21st century. Annals of Saudi Medicine, 2010, 30(1):37-46.

22. Clinical management of human infection with Pandemic H1N1: revised guidance. Geneva, World Health Organization, 2009 (www.who.int/entity/csr/resources/publications/swineflu/ clinicalmanagement/en, accessed 07 November 2009

23. Updated interim recommendation from the use of antiviral treatment and prevention of influenza from 2009-2010 season. Atlanta, Georgia, Centers for Disease Control and Prevention, 2009 (http://www.cdc.gov/h1n1flu/recommendations.htm, accessed 7 December 2009).

24. Clinical management of pandemic H1N1 2009 virus infection. Interim guidance from Expert Consultation. Cairo, World Health Organization, Eastern Mediterranean Regional Office, 2009 (http://who.emro.who.int/csr/h1n1/clinical_management. htm, accessed 10 October 2009).

25. Recommendations for the post-pandemic period. Geneva, World Health Organization, 2009 (Pandemic (H1N1) 2009 briefing note 23) (http://www.who.int/csr/disease/swineflu/ notes/briefing_20100810/en/index.html, accessed 5 October 2010). 